\title{
TITLE:
}

\section{Characteristics of carbonaceous aerosols emitted from peatland fire in Riau, Sumatra, Indonesia}

\section{$\operatorname{AUTHOR}(S)$ :}

Fujii, Yusuke; Iriana, Windy; Oda, Masafumi;

Puriwigati, Astiti; Tohno, Sususmu; Lestari, Puji;

Mizohata, Akira; Huboyo, Haryono Setiyo

\section{CITATION:}

Fujii, Yusuke ... [et al]. Characteristics of carbonaceous aerosols emitted from peatland fire in Riau, Sumatra, Indonesia. Atmospheric Environment 2014, 87: 164-169

\section{ISSUE DATE:}

2014-04

URL:

http://hdl.handle.net/2433/237621

\section{RIGHT:}

(c) 2014. This manuscript version is made available under the CC-BY-NC-ND 4 . license

http://creativecommons.org/licenses/by-nc-nd/4.0/; The full-text file will be made open to the public on 1 April 2016 in accordance with publisher's 'Terms and Conditions for Self-Archiving'; This is not the published version. Please cite only the published version.; この論文は出版社版でありません。引用の際には出版社版をご確認ご利用ください。 


\title{
Characteristics of carbonaceous aerosols emitted from peatland fire in Riau, Sumatra, Indonesia
}

\author{
Yusuke Fujii1 ${ }^{1 *}$, Windy Iriana ${ }^{2}$, Masafumi Oda ${ }^{1}$, Astiti Puriwigati ${ }^{2}$, \\ Susumu Tohno ${ }^{1}$, Puji Lestari ${ }^{2}$, Akira Mizohata ${ }^{3}$, Haryono Setiyo Huboyo ${ }^{1}$ \\ ${ }^{1}$ Department of Socio-Environmental Energy Science, Graduate School of Energy Science, Kyoto \\ University, Sakyo-ku, Kyoto 606-8501, Japan. \\ ${ }^{2}$ Department of Environmental Engineering, Bandung Institute of Technology, JL. Ganesha No. \\ 10, Bandung 40132, Indonesia. \\ ${ }^{3}$ Radiation Research Center, Osaka Prefecture University, Sakai, Osaka 599-8531, Japan.
}

\section{Abstract}

Biomass burning is a significant source of fine particulate matter $\left(\mathrm{PM}_{2.5}\right)$. Forest, bush, and peat fires in Kalimantan and Sumatra, Indonesia are major sources of transboundary haze pollution in Southeast Asia. However, limited data exist regarding the chemical characteristics of aerosols at sources. We conducted intensive field studies in Riau Province, Sumatra, Indonesia, during the peatland fire and non-burning seasons in 2012. We characterized $\mathrm{PM}_{2.5}$ carbonaceous aerosols emitted from peatland fire based on ground-based source-dominated sampling. $\mathrm{PM}_{2.5}$ aerosols were collected with two mini-volume samplers using Teflon and quartz fiber filters. Background aerosols were also sampled during the transition period between the non-burning and fire seasons. We analyzed the carbonaceous content (organic carbon (OC) and elemental carbon (EC)) by a thermal optical reflectance utilizing the IMPROVE_A protocol and the major organic components of the aerosols by a gas chromatography/mass spectrometry. $\mathrm{PM}_{2.5}$ aerosols emitted from peatland fire were observed in high concentrations of $7120 \pm 3620 \mu \mathrm{g} / \mathrm{m}^{3}$ and were primarily composed of OC (71.0 $\pm 5.11 \%$ of $\mathrm{PM}_{2.5}$ mass). Levoglucosan exhibited the highest total ion current and was present at concentrations of $464 \pm 183 \mu \mathrm{g} / \mathrm{m}^{3}$. The OC/EC ratios (36.4 \pm 9.08), abundances of eight thermally-derived carbon fractions, OC/Levoglucosan ratios (10.6 \pm 1.96), and Levoglucosan/Mannosan ratios (10.6 \pm 2.03$)$ represent a signature profile that is inherent in peatland fire. These data will be useful in identifying contributions from single or multiple species in atmospheric aerosol samples collected from peatland fires.

Keywords: Carbonaceous aerosol; $\mathrm{PM}_{2.5}$; Levoglucosan; Mannosan; Biomass Burning

\footnotetext{
${ }^{*}$ Corresponding author. Tel: +81-75-753-5618; Fax: +81-75-753-5619

E-mail address: fujii.yusuke.86n@st.kyoto-u.ac.jp
} 


\section{$35 \quad$ Highlights}

36

$37>\mathrm{PM}_{2.5}$ aerosols emitted from peatland fire in Indonesia were characterized.

$38>\mathrm{PM}_{2.5}$ aerosols emitted from peatland fire were primarily composed of OC.

$39>$ We found some source indicators that were inherent in peatland fire.

40 


\section{Introduction}

Peatland is organic soil that has formed for over thousands of years from decomposed vegetation and other life forms, and peat deposits can extend up to seven meters in thickness (Wulandari, 2002). In Southeast Asia, smoke originating from peatland fires in Kalimantan and Sumatra in Indonesia is a major cause of transboundary haze pollution.

In general, approximately $80-90 \%$ of the smoke particles produced by biomass burning is in the $\mathrm{PM}_{2.5}$ size range, and these particles are primarily composed of organic carbon, which constitutes $50-60 \%$ of the total particle mass (Phuleria et al., 2005; Schollnberger et al., 2002; Reid et al., 2005). $\mathrm{PM}_{2.5}$ aerosols present a high risk of deposition in the alveoli of lungs and are associated with a greater general health risk than coarse aerosols (Federal Register, 2006; Lippmann, 1998).

According to version 3 of the Global Fire Emissions Database (GFED), average $\mathrm{PM}_{2.5}$ emissions from fire (including deforestation, savanna, forest, agricultural waste, and peat fires) from 1997 to 2010 in Indonesia are 2.9 Tg/year, accounting for 9.2\% of global fire PM$_{2.5}$ emissions and 62\% of Southeast Asian fire emissions. In Indonesia, peatland fire is a dominant source of $\mathrm{PM}_{2.5}$ emissions, accounting for $55 \%$ of all fire sources. Thus, it is a significant emission source of $\mathrm{PM}_{2.5}$ aerosols in Indonesia.

Many peatland fires occur on Sumatra and Kalimantan islands during the dry season, emitting 
gases and smoke aerosols that cause atmospheric pollution (haze) and adversely affect the health

61 of people living in surrounding areas. For example, an unprecedented Indonesian fire episode occurred in 1997-1998 due to the El Niño-Southern Oscillation (ENSO) event at that time. Extensive forest fires, including peatland fires, resulted in the development of a smog blanket that covered an immense area of 4 million $\mathrm{km}^{2}$ in Southeast Asia. This smog affected the livelihoods and health of 75 million people in six countries and completely toppled their lives. Moreover, the smog resulted in the closure of airports; it was cited as the possible cause of an air crash near Medan, Sumatra, and a tanker collision in the Straits of Malacca (Stolle and Tomich, 1999). Air pollution attained previously unknown levels in East Kalimantan, Singapore, and Kuala Lumpur,

69 with daily average particulate matter reaching extremely hazardous levels $\left(4000 \mu \mathrm{g} / \mathrm{m}^{3}\right.$; Heil et al., 1998). Although ENSO events considerably contribute to the occurrence of Indonesian fires,

71 pollution from smoke haze is a recurrent problem in Indonesia and neighboring countries, even in non-ENSO years (Tacconi, 2003).

Riau Province in Sumatra is one of the primary hotspots for peatland fire during the dry season, and the smoke aerosols generated there cause haze in Riau and in neighboring countries such as Malaysia and Singapore (Harahap, 2012; Hong, 2012). However, limited data exist regarding the chemical characteristics of these smoke aerosols (Othman and Latif, 2013; See et al, 2007) and the effects of aerosols from peatland fires on the atmospheric environment and human health. To 
78 investigate these effects, the chemical characterization of fresh smoke aerosols from peatland fire

79 is necessary. In this study, the carbonaceous species of $\mathrm{PM}_{2.5}$ aerosols emitted from peatland fire

80 were characterized by directly sampling $\mathrm{PM}_{2.5}$ aerosols at fire hotspots in Riau Province.

81 Moreover, we determined source indicators of carbonaceous species of smoke from peatland fires

82 for source apportionment. These data can help in identifying single or multiple species in

83 atmospheric aerosol samples that contribute to peatland fires.

\section{Materials and methods}

87

88

\subsection{Sampling locations}

89

90

The sampling locations in this study are illustrated in Fig. 1. The burning site and background

91 site were located at Sepahat Village and Sukajadi Village, respectively, in Bengkalis Regency,

Riau Province. The burning site was surrounded by peatland and forest, and the background site 
99 rainy season generally lasts from September to January, with an average rainfall of 809-4078

$100 \mathrm{~mm} / \mathrm{year}$, and the dry season usually spans February to August. Fig. 2 illustrates monthly hotspot

101 counts in Riau in 2011 and 2012 based on Indofire datasets, confirming that many hotspots are

102 detected in the area during the dry season.

103

104

105

106

107

108

109

110

111

112

113

114

115

116

117

118

\subsection{Sample collection and analysis}

In 2012, background and peatland fire $\mathrm{PM}_{2.5}$ aerosol samples were collected on May 16-17 and June 13-17, respectively. Two mini-volume samplers (MiniVol ${ }^{\mathrm{TM}} \mathrm{TAS}$, Airmetrics) were utilized to continuously collect $\mathrm{PM}_{2.5}$ aerosols on Teflon and quartz fiber filters for $24 \mathrm{~h}$ (background) and 2.5-5.2 h (peatland fire), respectively, at a flow rate of $5 \mathrm{~L} / \mathrm{min}$. $\mathrm{PM}_{2.5}$ aerosols were collected at several burning sites, about $1.5 \mathrm{~m}$ away from peatland fire hotspots and a background site on 7 and 4 occasions, respectively. Wind speeds in the peatland fire samplings ranged from 0.610 to $6.21 \mathrm{~m} / \mathrm{s}$ (average: $2.50 \mathrm{~m} / \mathrm{s}$ ) and aerosols were collected in smoke plumes.

Quartz fiber filters were heat-treated at $900^{\circ} \mathrm{C}$ for $4 \mathrm{~h}$ before sampling to remove any absorbed organic materials.

Filter samples were analyzed to determine $\mathrm{PM}_{2.5}$ mass concentrations, carbonaceous content (organic carbon (OC) and elemental carbon (EC)), and the quantity of key biomarkers.

The Teflon filter was weighed using a microbalance (ME5-F, Sartorius) with a sensitivity of \pm 1 $\mu \mathrm{g}$ in a stable environment of $25.7 \pm 0.432^{\circ} \mathrm{C}$ (average \pm standard deviation) and $26.0 \pm 0.607$ 
119 RH\% before and after sampling, respectively, to determine $\mathrm{PM}_{2.5}$ mass concentrations.

120 The carbonaceous contents of the aerosols collected in the quartz fiber filters were quantified

121 using a DRI Model 2001 OC/EC Carbon Analyzer, which employs thermal optical reflectance

122 following the IMPROVE_A protocol. The IMPROVE_A temperature defines temperature

123 plateaus for thermally-derived carbon fractions as follows: $140^{\circ} \mathrm{C}$ for $\mathrm{OC}_{1}, 280^{\circ} \mathrm{C}$ for $\mathrm{OC}_{2}$,

$124480^{\circ} \mathrm{C}$ for $\mathrm{OC}_{3}$, and $580^{\circ} \mathrm{C}$ for $\mathrm{OC}_{4}$ in helium (He) carrier gas; $580^{\circ} \mathrm{C}$ for $\mathrm{EC}_{1}, 740^{\circ} \mathrm{C}$ for $\mathrm{EC}_{2}$,

125 and $840^{\circ} \mathrm{C}$ for $\mathrm{EC}_{3}$ in a mixture of $98 \% \mathrm{He}$ and $2 \%$ oxygen $\left(\mathrm{O}_{2}\right)$ carrier gas (Chow et al., 2007).

126 OC, EC, and total carbon (TC) were calculated from the eight carbon fractions as follows:

127

$128 \quad \mathrm{OC}=\mathrm{OC}_{1}+\mathrm{OC}_{2}+\mathrm{OC}_{3}+\mathrm{OC}_{4}+\mathrm{OP}$

129

130

$\mathrm{EC}=\mathrm{EC}_{1}+\mathrm{EC}_{2}+\mathrm{EC}_{3}-\mathrm{OP}$

131

$132 \mathrm{TC}=\mathrm{OC}+\mathrm{EC}$

where OP (the amount of pyrolyzed OC) is defined as the carbon content measured after the introduction of $\mathrm{O}_{2}$ until reflectance returns to its initial value at the start of analysis.

Two key biomarkers, levoglucosan and mannosan, obtained from the quartz fiber filters were

quantified by gas chromatography/mass spectrometry (GC/MS). Organic compound speciation

was basically accomplished, following the procedures of Fabbri et al., 2009 and Pashynska et al.,

2002. Aliquots from the quartz fiber filter were spiked with the internal standard of methyl 
141 for $3 \times 20$ min periods using $3 \mathrm{~mL}$ of a dichloromethane/methanol mixture (3/1, v/v)

142 (dichloromethane: Wako, purity >99.5\%; methanol: Wako, purity >99.7\%). The combined

143 extracts were reduced to approximately $100 \mu \mathrm{L}$ using a rotary evaporator $\left(250 \mathrm{hPa}, 40^{\circ} \mathrm{C}\right.$ ).

144 Subsequently, the concentrated extract was filtered through a Teflon syringe filter (pore size 0.1

$145 \mu \mathrm{m})$ and dried completely under a nitrogen stream. Prior to analysis, the total extracts were

146 converted to trimethylsilyl derivatives by reaction with $150 \mu \mathrm{L}$ of

147 N,O-bis-(trimethylsilyl)-trifluoroacetamide with 1\% trimethylchlorosilane and $90 \mu \mathrm{L}$ of pyridine

148 for $3 \mathrm{~h}$ at $70^{\circ} \mathrm{C}$.

149 The derivatized samples were analyzed on a Shimadzu GC/MS system (GCMS-QP2010-Plus,

150 Shimadzu) equipped with an Rtx-5Sil MS column (with selectivity similar to that of a mixture of

$1515 \%$ diphenyl and 95\% dimethyl polysiloxane, $30 \mathrm{~m} \times 0.25 \mathrm{~mm}$ I.D., $0.25 \mu \mathrm{m}$, RESTEK). Helium

152 (purity 99.9995\%) with an average velocity of $35.3 \mathrm{~cm} / \mathrm{s}$ was used as the carrier gas. The GC

153 oven temperature program was as follows: isothermal at $80^{\circ} \mathrm{C}$ for $5 \mathrm{~min}, 80-180^{\circ} \mathrm{C}$ at $3^{\circ} \mathrm{C} / \mathrm{min}$,

154 then $180-300^{\circ} \mathrm{C}$ at $20^{\circ} \mathrm{C} / \mathrm{min}$, and maintained at $300^{\circ} \mathrm{C}$ for $5 \mathrm{~min}$. The injection port and transfer

155 line were maintained at $300^{\circ} \mathrm{C}$. The data for quantitative analysis were acquired in the electron 156 impact mode (70 eV). 


\section{1. $P M_{2.5}$ mass concentration}

Background and peatland fire $\mathrm{PM}_{2.5}$ concentrations determined by gravimetric analysis were $23.9 \pm 2.53 \mu \mathrm{g} / \mathrm{m}^{3}$ and $7120 \pm 3620 \mu \mathrm{g} / \mathrm{m}^{3}$, respectively; that is, peatland fire $\mathrm{PM}_{2.5}$ concentrations were $~ 300$ times higher than background concentrations. These extremely high $\mathrm{PM}_{2.5}$ concentrations present a great risk to human health, particularly in the case of fire fighters.

Since the high concentration is due to the sampling at $1.5 \mathrm{~m}$ away from the fire, a different value would be obtained in the different sampling distance.

\subsection{OC and EC}

The average OC concentrations from peatland fire and background were $4970 \pm 3620 \mu \mathrm{g} / \mathrm{m}^{3}$ and $9.42 \pm 1.97 \mu \mathrm{g} / \mathrm{m}^{3}$, respectively, and average EC concentrations were $133 \pm 46.6 \mu \mathrm{g} / \mathrm{m}^{3}$ and $3.23 \pm 0.795 \mu \mathrm{g} / \mathrm{m}^{3}$, respectively. In terms of the carbonaceous fractions in $\mathrm{PM}_{2.5}$ aerosols, $\mathrm{PM}_{2.5}$ aerosols emitted from peatland fire were composed of $71.0 \pm 5.11 \%$ OC and $2.05 \pm 0.509 \%$ EC.

Conversely, background $\mathrm{PM}_{2.5}$ aerosols were composed of $39.1 \pm 5.08 \%$ OC and $13.5 \pm 3.04 \%$

EC. The remaining undetermined mass can be attributed to the various functional groups in organic aerosols, inorganic ions, metals, soil and particle bound water.

OC to EC mass ratios (OC/EC) provide some indication of the origins of carbonaceous $\mathrm{PM}_{2.5}$

(Cao et al., 2005; Chow et al., 1996; Gray et al., 1986; Turpin and Huntzicker, 1991). In this study, the average peatland fire and background OC/EC ratios were $36.4 \pm 9.08$ and $2.99 \pm 0.738$, 
182 respectively. Few differences in the OC/EC ratio were observed, regardless of $\mathrm{PM}_{2.5}$ mass

183 concentrations, and the coefficient of variance for samples from peatland fire was $24.9 \%$. See et

184 al., 2007 reported that the average OC/EC ratio was 2.42 for $\mathrm{PM}_{2.5}$ aerosols collected in the open

185 field within a 100 m circumference from the boundary of the Indonesian peatland fires in 2005.

186 This value is much smaller than our result of 36.4. The discrepancy is due to the different

187 measurement techniques for the OC-EC split. See et al., 2007 adopted thermal method whose temperature of OC-EC split was $350^{\circ} \mathrm{C}$. The method would cause significant overestimation of EC concentration in aerosol (Gelencsér, 2004). On the other hand, we utilized thermal-optical

190 reflectance method with pyrolysis correction. OC/EC ratios from our peatland fire and other vegetative burning sources are illustrated in Fig. 3. OC/EC ratios ranged from 4.34 to 79.7; this discrepancy can be partly attributed to variations in the type and moisture content of the burning material.

194 Abundances of eight thermally-derived carbon fractions differ by carbon sources (Cao et al.,

195 2005; Chow et al., 2004; Watson et al., 1994). Fig. 4 illustrates the abundances of eight 196 thermally-derived carbon fractions at both the peatland fire and background sites by mass 197 percentage of total carbon. Distinct differences in carbon fractions were observed between the 198 two sites. OC $_{1}$ accounted for $31.7 \pm 2.21 \%$ of TC in peatland fire samples but only $0.710 \pm$ $1990.721 \%$ of TC in background samples. OC 2 accounted for $47.5 \pm 0.948 \%$ of TC in peatland fire 
200 samples and $13.9 \pm 1.64 \%$ of TC in background samples. OC $_{3}$ accounted for $7.44 \pm 1.57 \%$ of TC

201 in peatland fire samples and $40.7 \pm 2.62 \%$ of TC in background samples. OC 4 accounted for 1.22

$202 \pm 0.412 \%$ of TC in peatland fire samples and $15.7 \pm 1.27 \%$ of TC in background samples. OP

203 accounted for $9.28 \pm 1.39 \%$ of $\mathrm{TC}$ in peatland fire samples and $3.95 \pm 4.13 \%$ of $\mathrm{TC}$ in

204 background samples. Lower EC fractions were observed in the peatland fire than the background

205 samples. Thus, it was found that TC in $\mathrm{PM}_{2.5}$ aerosols derived from peatland fires was primarily

206 composed of $\mathrm{OC}_{1}$ and $\mathrm{OC}_{2}$.

207 Fig. 5 illustrates the average percentages of eight fractions in $\mathrm{PM}_{2.5}$ for the peatland fire 208 samples and those from other sources. The vegetation burning profiles used as reference were 209 obtained by ground-based source-dominated sampling of the plumes of small controlled burns of 210 wood debris at the Big Bend National Park in the US (see Chow et al., 2004). The carbon fraction 211 abundances differ by emission source: $\mathrm{OC}_{1}$ is enriched $(23.9 \pm 12.4 \%)$ in the vegetative burning 212 profile; $\mathrm{OC}_{2}$ is enriched $(34.7 \pm 2.16 \%)$ in the peatland fire profile; $\mathrm{OC}_{3}$ is enriched $(37.6 \pm$ $21315.9 \%)$ in the cooking profile; $\mathrm{EC}_{2}$ is enriched $(23.3 \pm 10.4 \%)$ in the motor vehicle profile. In 214 terms of the coefficient of variance, the carbon fraction obtained from peatland fire is more 215 consistent than any source presented in Fig. 5. Thus, the peatland profile will be useful for source 216 discrimination. 
The organic compounds produced by peatland fires were analyzed by GC/MS, and an example

221 of typical GC/MS total ion current (TIC) tracers for the total extract of peatland fire samples is

222 presented in Fig. 6. Levoglucosan clearly exhibits the highest TIC peak in peatland fire samples,

223 although mannosan and palmitic acid were also detected. Palmitic acid is one of the most basic

224 units of plant fats, oils, and phospholipids (Simoneit, 2002). The major tracers in smoke emitted

225 from biomass burning are the thermal degradation (pyrolysis) products of the biopolymers of

226 cellulose and lignin in woody tissue. The thermal degradation of cellulose (also hemicelluloses)

227 yields dehydromonosaccharide derivatives, which are predominant compounds in the smoke

228 (Simoneit et al., 1999). The major compound is levoglucosan, with minor and variable amounts

229 of galactosan and mannosan. These compounds cannot be formed by hydrolysis or by the

230 microbial alteration of carbohydrates; thus, they are specific to burning (Simoneit et al., 1999). In

231 addition, levoglucosan is considerably resistant to atmospheric degradation (Fraser and

232 Lakshmanan, 2000). Therefore, levoglucosan and mannosan are regarded as key biomarkers in

233 peatland fire aerosols like other biomass burnings.

234 The average levoglucosan concentrations from peatland fire and background samples were 464

$235 \pm 183 \mu \mathrm{g} / \mathrm{m}^{3}$ and $0.278 \pm 0.155 \mu \mathrm{g} / \mathrm{m}^{3}$, respectively and the average mannosan concentration

236 were $47.5 \pm 25.6 \mu \mathrm{g} / \mathrm{m}^{3}$ and $0.0190 \pm 0.0108 \mu \mathrm{g} / \mathrm{m}^{3}$, respectively. Levoglucosan and mannosan in

237 background samples may have originated from wood burning for cooking, agricultural use, 
238 among others. However, concentrations of levoglucosan and mannosan emitted in association

239 with peatland fire events were much higher than their corresponding background concentrations.

240 OC/Levoglucosan ratios vary to some extent for different burning conditions and wood types

241 (Pio, et al., 2008). In this study, the average OC/Levoglucosan ratio in peatland fire was $10.6 \pm$

$2421.96 \mu \mathrm{gC} / \mu \mathrm{g}$. For comparison of our peatland fire samples with biomass burning samples, the

243 average OC/Levoglucosan ratios for various source samples are presented in Fig. 7, which shows

244 significant differences in OC/Levoglucosan ratios between the peatland fire and other emission

245 sources. Thus, this ratio may be useful for source discrimination for peatland fire. However,

246 because levoglucosan is emitted from other biomass burning sources and there are other types of

247 biomass burning in Riau, Sumatra, Indonesia, selection of only OC/Levoglucosan ratio for source

248 apportionment of peatland fire can lead to overestimation of the contribution of peatland fire.

249 Hence, other indicators for peatland fire are needed.

250 The relative amounts of the individual anhydrosaccharides in biomass smoke aerosols can be

251 used for further source assignment of specific biofuels (Fabbri et al., 2009; Alves et al., 2010).

252 Here, we investigated the Levoglucosan/Mannosan ratios and compared those ratios from

253 peatland fire and other biomass burning sources. In this study, the average

254 Levoglucosan/Mannosan ratios in peatland fire and background were $10.6 \pm 2.03$ and $14.5 \pm 3.39$,

255 respectively. For comparison of our peatland fire samples with other biomass burning samples, 
256 the average Levoglucosan/Mannosan ratios for various source samples are presented in Table 1,

257 which shows the significant differences in Levoglucosan/Mannosan ratios between the peatland

258 fire and other emission sources. Thus, this ratio should be more useful for source discrimination

259 for peatland fire than OC/Levoglucosan ratio.

\section{Conclusions}

263

$264 \quad \mathrm{PM}_{2.5}$ carbonaceous aerosols were collected at a peatland fire hotspots and a background site 265 on 7 and 4 occasions, respectively. $\mathrm{PM}_{2.5}$ aerosols emitted from peatland fire were observed in 266 very high concentrations $\left(7120 \pm 3620 \mu \mathrm{g} / \mathrm{m}^{3}\right)$ and were primarily composed of OC $(71.0 \pm$ $267 \quad 5.11 \%$ of $\mathrm{PM}_{2.5}$ mass).

The OC/EC ratios (36.4 \pm 9.08 for peatland fire), abundances of eight thermally-derived

269 carbon fractions, OC/Levoglucosan ratios (10.6 \pm 1.96 for peatland fire), and

270 Levoglucosan/Mannosan ratios (10.6 \pm 2.03 for peatland fire) observed here represent a signature

271 profile that seems to be inherent in peatland fire emissions. Therefore, it is suggested that such 272 profiles are useful for peatland fire source discrimination.

In future studies, additional chemical speciation for fresh and aged smoke from peatland fires will be required to estimate atmospheric environmental impacts and/or adverse health effects (e.g., humic-like substances, polycyclic aromatic hydrocarbons). 


\section{Acknowledgement}

This study was partially supported by funds from the Grants-in Aid for Innovative Areas under

281 Grant No. 2012005 from the Japanese Ministry of Education, Culture, Sports, Science and 282 Technology (MEXT).

\section{References}

286

Alves, C.A., Gonçalves, C., Evtyugina, M., Pio, C.A., Mirante, F., Puxbaum, H., 2010.

Cao, J.J., Wu, F., Chow, J.C., Lee, S.C., Li, Y., Chen, S.W., An, Z.S., Fung, K.K., Watson, J.G.,

291 Zhu, C.S. and Liu, S.X., 2005. Characterization and Source Apportionment of Atmospheric

292 Organic and Elemental Carbon during Fall and Winter of 2003 in Xi'an, China. Atmos. Chem.

293 Phys. 5: 3127-3137.

294 Chow, J.C., Watson, J.G., Lu, Z., Lowenthal, D.H., Frazier, C.A., Solomon, P.A., Thuillier, R.H. 
297 Chow, J.C., Watson, J.G., Chen, L.-W.A., Chang, M.C.O., Robinson, N.F., Trimble, D. and Kohl, 298 S., 2007. The IMPROVE_A Temperature Protocol for Thermal/Optical Carbon Analysis:

299 Maintaining Consistency with a Long-Term Database. J. Air Waste Manage. Assoc. 57: 1014$300 \quad 10023$.

301 Chow, J.C., Watson, J.G., Kuhns, H.D., Etyemezian, V., Lowenthal, D.H., Crow, D.J., Kohl, S.D., 302 Engelbrecht, J.P. and Green, M.C., 2004. Source Profiles for Industrial, Mobile, and Area 303 Sources in Big Bend Regional Aerosol Visibility and Observational (BRAVO) Study. Chemosphere 54: 185-208.

Fabbri, D., Torri, C., Simoneit, B.R.T., Marynowski, L., Rushdi, A.I., Fabiańska, M.J., 2009.

Levoglucosan and Other Cellulose and Lignin Markers in Emissions from Burning of Miocene

Federal Register, 2006. National Ambient Air Quality Standards for Particulate Matter: Final

309 Rule. 40 CFR Parts 50, 53, and 58, volume 62 (138), October 17, 2006, U.S. EPA, Office of 310 Air and Radiation, Office of Air Quality Planning and Standards, Research Triangle Park, NC.

311 Fraser, M.P. and Lakshmanan, K., 2000. Using Levoglucosan as a Molecular Marker for the Long-range Transport of Biomass Combustion Aerosols. Environ. Sci. Technol. 34, 4560-4564.

313 Gelencsér, A., 2004. Carbonaceous Aerosol, Springer, p.32.

314 GFED. [online] [Accessed 17 July 2013]. Available: http://www.globalfiredata.org/. 
315 Gray, H.A., Cass, G.R., Huntzicker, J.J., Heyerdahl, E.K. and Rau, J.A., 1986. Characteristics of 316 Atmospheric Organic and Elemental Carbon Particle Concentrations in Los Angeles. Environ.

317 Sci. Technol. 20: 580-589.

318 Harahap, R., 2012. As dry season returns to Riau, so do fires and choking haze. The Jakarta Post,

319 June 13. [online] [Accessed 17 July 2013]. Available:

320 http://www.thejakartapost.com/news/2012/06/13/as-dry-season-returns-riau-so-do-fires-and-ch oking-haze.html.

Heil, A., Stolle, F., Mahmud, M. and Effendi, E., 1998. Air Pollution from Large Scale Forest and Land Fires in Indonesia 1997-1998: Development and Impacts. The First Synthesis Working Group Meeting on Land Use Planning and Management to Reduce Transboundary Pollution from Fires in Southeast Asia. Bongor, Indonesia, 18-19 August 1998.

Hong C., 2012. 'Indonesian'-made haze covers parts of KL, surrounding areas. The Straits Times,

327 June 16. [online] [Accessed 17 July 2013]. Available: http://www.thejakartapost.com/news/2012/06/16/indonesian-made-haze-covers-parts-kl-surrou 329 nding-areas.html.

330 Indofire. [online] [Accessed 17 July 2013]. Available: http://www.indofire.org/indofire/hotspot.

331 Lee, S., Baumann, K., Schauer, J.J., Sheesley, R.J., Naeher, L.P., Simone, M., Blake, D.R., 
Prescribed Burning in Georgia. Environ. Sci. Technol. 39: 9049-9056.

334 Lippmann M., 1998. In The 1997 US EPA Standards for Particulate Matter and Ozone. Issues

Environ. Sci. Tech. 10, Hester, R.E. and Harrison, R.M. (Eds.), Royal Society of Chemistry:

$336 \quad 75-99$

Lubis, A.M. and Harahap, R., 2013. Only rain can help S’pore now. The Jakarta Post, June 21.

[online] [Accessed 17 July 2013]. Available:

http://m.thejakartapost.com/news/2013/06/21/only-rain-can-help-s-pore-now.html.

340 Othman, M. and Latif, M.T., 2013. Dust and Gas Emissions from Small-Scale Peat Combustion.

$341 \quad$ Aerosol Air Qual. Res. 13: 1045-1059.

342 Phuleria, H.C., Fine, P.M., Zhu, Y., and Sioutas, C., 2005. Air Quality Impacts of the October

3432003 Southern California Wildfires. J. Geophys. Res. 110, D07S20, doi:

$344 \quad$ 10.1029/2004JD004626.

345 Pio, C.A., Legrand, M., Alves, C.A., Oliveria, T., Afonso, J., Caseiro, A., Puxbaum, H.,

346 Sanchez-Ochoa, A. and Gelensér, A., 2008. Chemical Composition of Atmospheric Aerosols

347 during the 2003 Summer Intense Forest Fire Period. Atmos. Environ. 42: 7530-7543.

348 Reid, J.S., Koppmann, R., Eck, T.F. and Eleuterio, D.P., 2005. A Review of Biomass Burning

349 Emissions Part II: Intensive Physical Properties of Biomass Burning Particles. Atmos. Chem. Phys. 5: 799-825. 
351 See, S.W., Balasubramanian, R., Rianawati, E., Karthikeyan, S. and Streets, D.G., 2007.

352 Characterization and Source Apportionment of Particulate Matter $\leq 2.5 \mu \mathrm{m}$ in Sumatra,

353 Indonesia, during a Recent Peat Fire Episode. Environ. Sci. Technol. 41: 3488-3494.

354 Sheesley R.J. and Schauer, J.J., 2003. Characterization of Organic Aerosols Emitted from the

355 Combustion of Biomass Indigenous to South Asia. J. Geophys. Res. 108, D9, 4285, doi:

$356 \quad$ 10.1029/2002JD002981.

357 Simoneit, B.R.T., 2002. Biomass Burning - A Review of Organic Tracers for Smoke from Incomplete Combustion. Appl. Geochem 17: 129-162.

Simoneit, B.R.T., Schauer, J.J., Nolte, C.J., Oros, D.R., Elias, V.O., Fraser, M.P., Rogge, W.F. and

Cass, G.R., 1999. Levoglucosan, A Tracer for Cellulose in Biomass Burning and Atmospheric

Stolle, F. and Tomich, T.P., 1999. The 1997-1998 Fire Event in Indonesia. Nat. Resour. 35: 22-30. 
369 Robbins, R., 1994. Differences in the Carbon Composition of Source Profiles for Diesel- and

$370 \quad$ Gasoline-powered Vehicles. Atmos. Environ. 28: 2493-2505.

371 Wulandari, F., 2002. Reckless Farming in Peatland Forests Major Cause of Fires. The Jakarta

Post, August 25. [online] [Accessed 17 July 2013]. Available:

373 http://www.thejakartapost.com/news/2002/08/25/reckless-farming-peatland-forests-major-caus e-fires.html. 


\section{Table Captions}

377 Table 1. Range of Levoglucosan/Mannosan ratios in $\mathrm{PM}_{2.5}$ emitted from several sources and 378 background.

379

380

381

382

383 
386

\begin{tabular}{ccc}
\hline & Levoglucosan/Mannosan & Reference \\
\hline Peatland fire & $7.09-14.0$ & this study \\
Background & $10.7-18.9$ & this study \\
Hardwoods burning & $13.8-52.3$ & Engling et al., 2006 \\
Softwoods burning & $2.6-5.0$ & Engling et al., 2006 \\
Grasses burning & $108-203$ & Engling et al., 2006 \\
\hline
\end{tabular}

387

388

389

390

391

392

393

394

395

396

Table 1. 
400 Fig. 1. Map of Bengkalis showing the sampling sites.

401 Fig. 2. Monthly hotspot counts in Riau in 2011 and 2012.

402 Fig. 3. Comparison of OC/EC ratios in $\mathrm{PM}_{2.5}$ emitted from peatland fire and other burning

403 sources. Error bar in this study indicates standard deviation.

404 Fig. 4. Abundances (as mass percentage of total carbon) of eight thermally-derived carbon

405 fractions of aerosols sampled at the peatland fire and background sites. Error bars indicate

406 standard deviations.

407 Fig. 5. Carbon fraction composition of $\mathrm{PM}_{2.5}$ combustion source profiles. Error bars indicate

408 standard deviations.

409 Fig. 6. GC/MS total ion current (TIC) chromatograph of total extract showing major compounds

410 of peatland fire aerosols.

411 Fig. 7. Comparison of OC/Levoglucosan ratios of $\mathrm{PM}_{2.5}$ obtained from peatland fire and other

412 burning sources. Error bar in this study indicates standard deviation. 


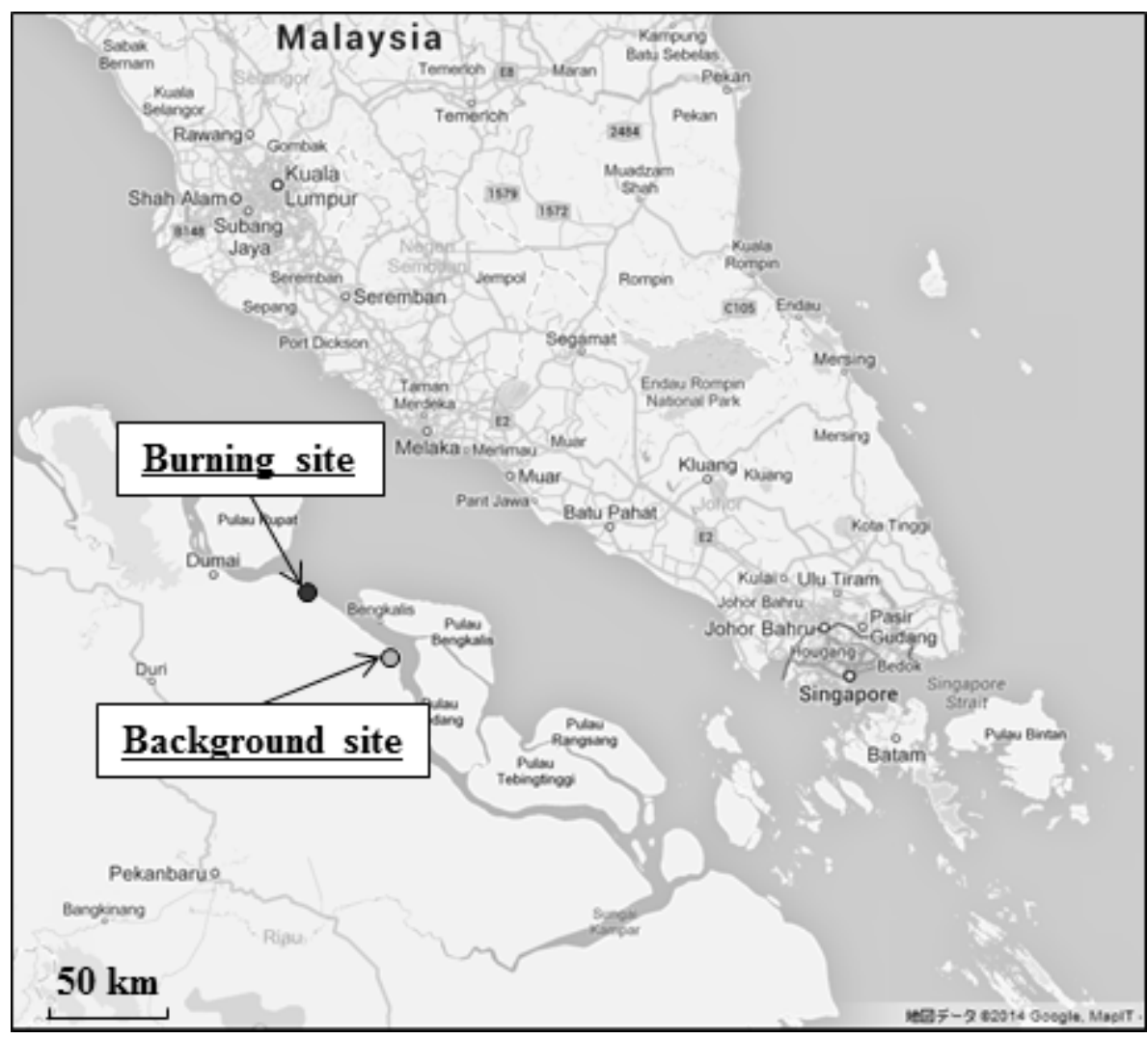




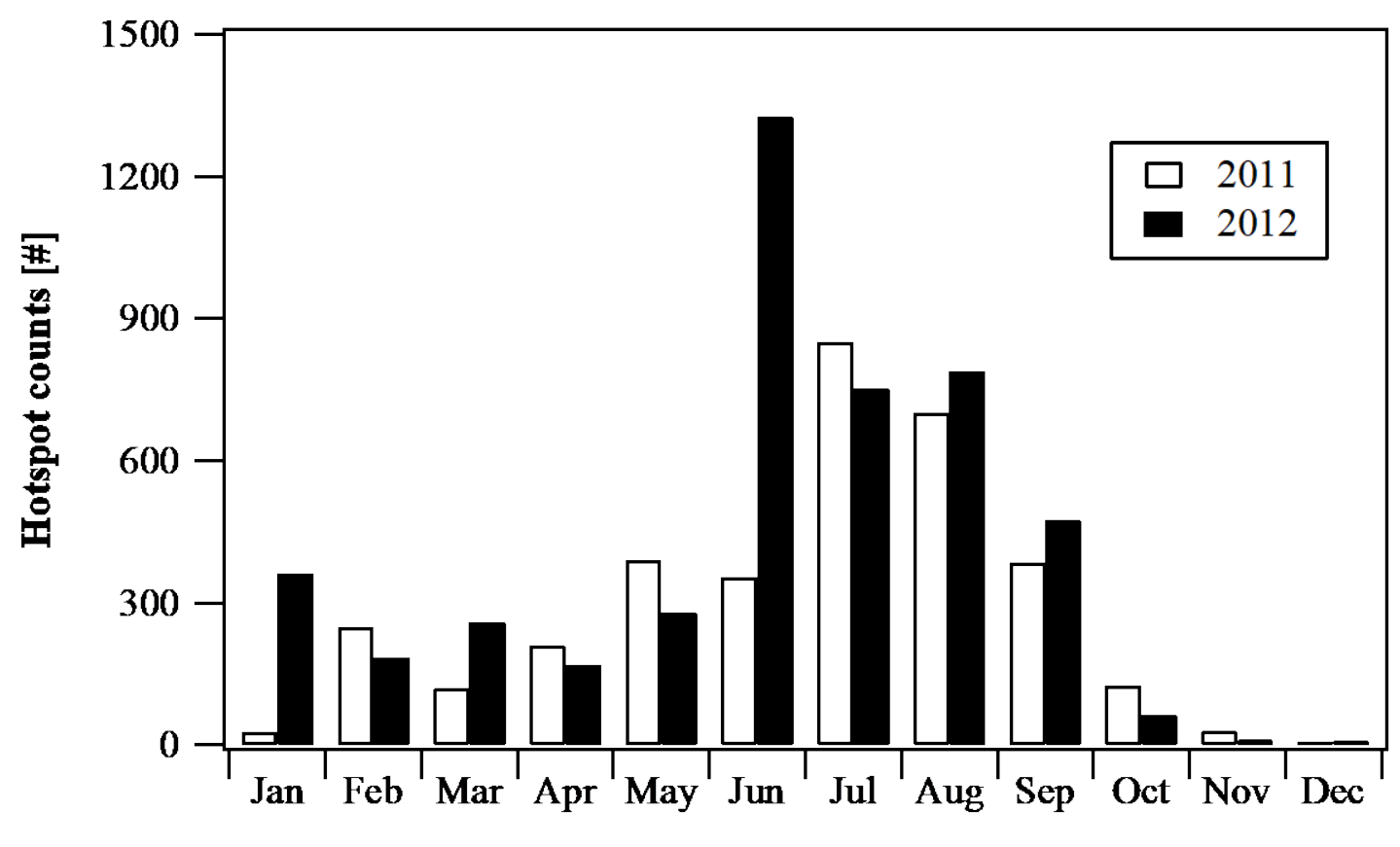




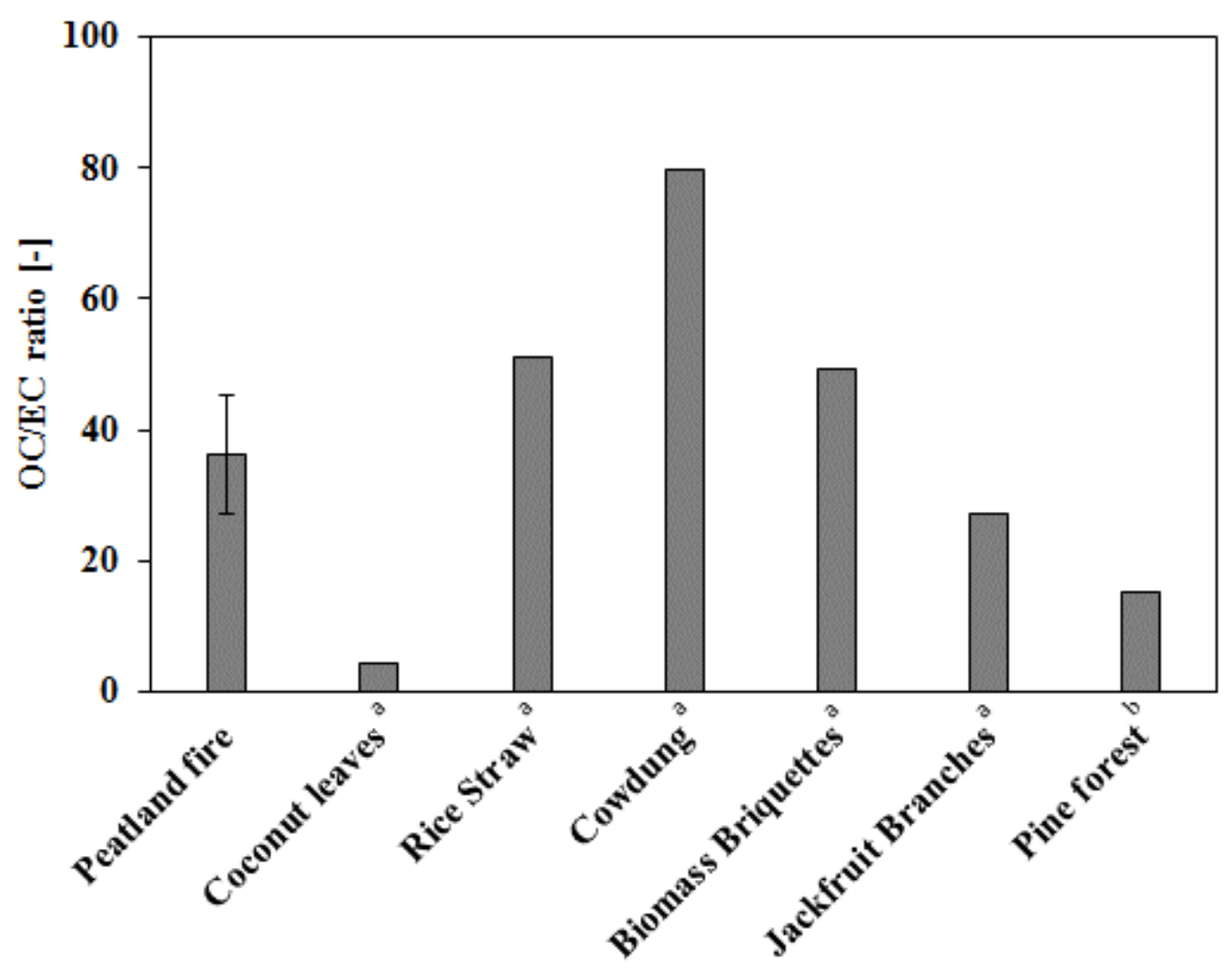

444 a data from Sheesley and Schauer, 2003, ${ }^{\text {b }}$ data from Lee et al., 2005. 


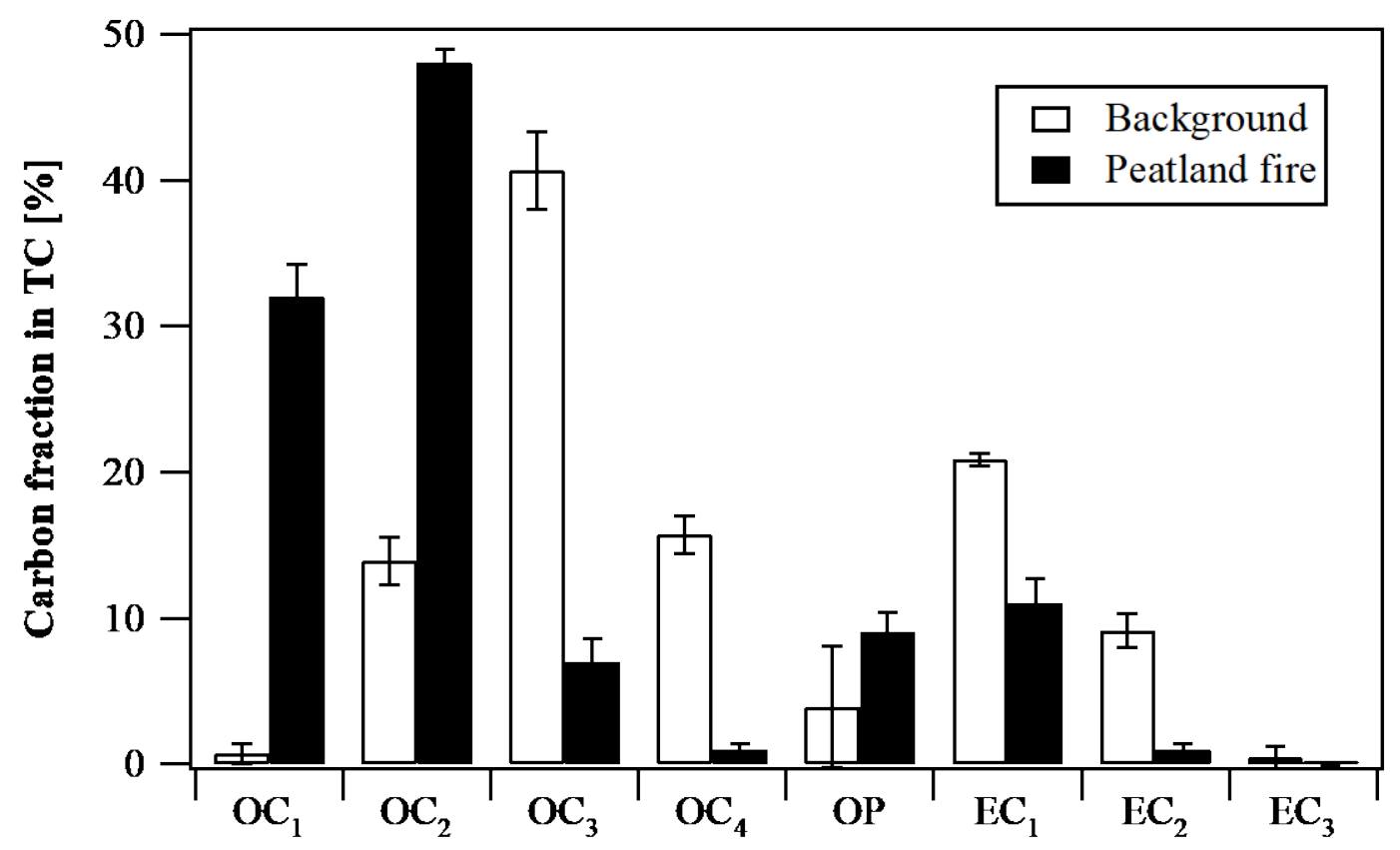

453

454

455

456

457 


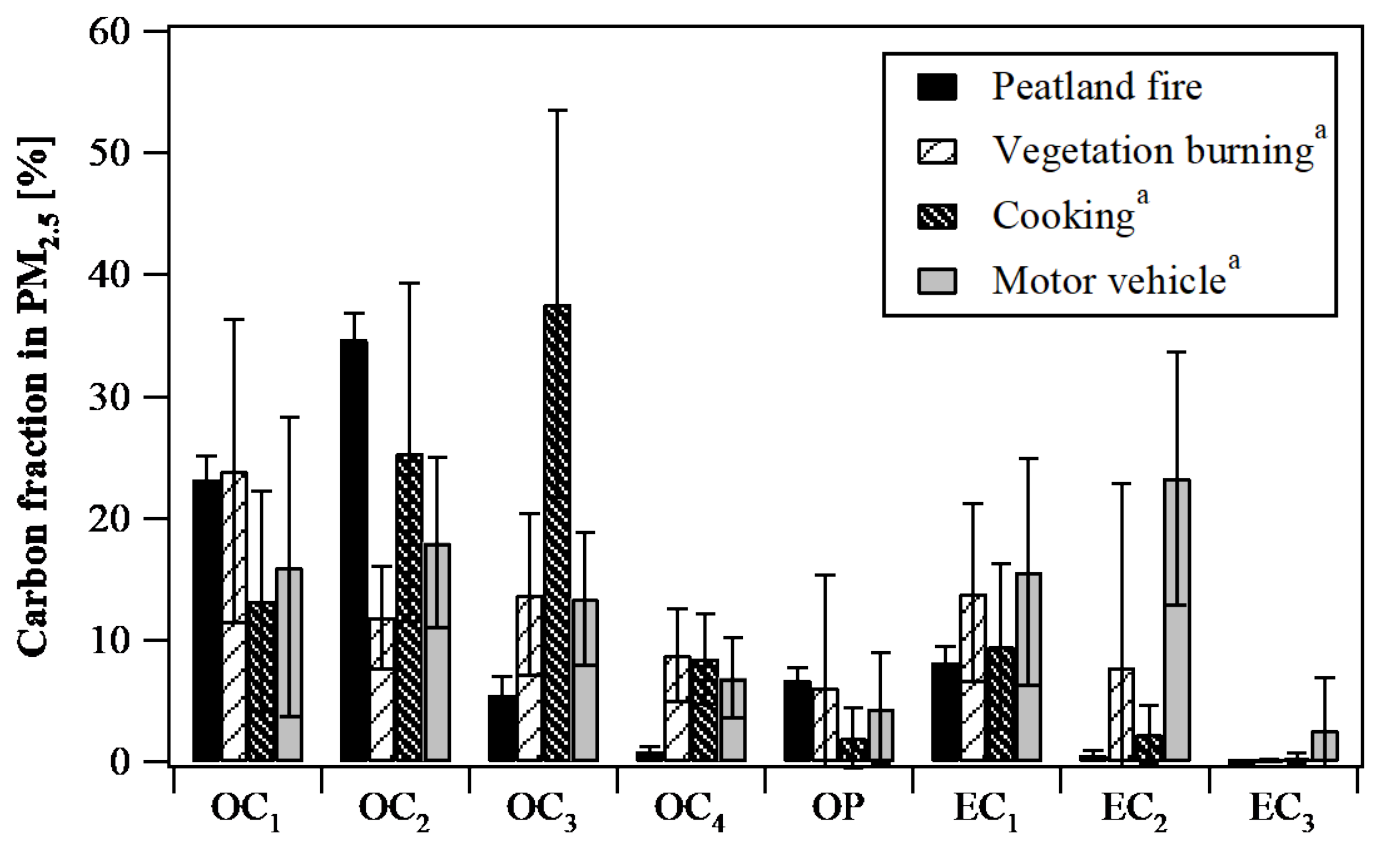

464

465

${ }^{a}$ data from Chow et al., 2004.

466

467

468

469 


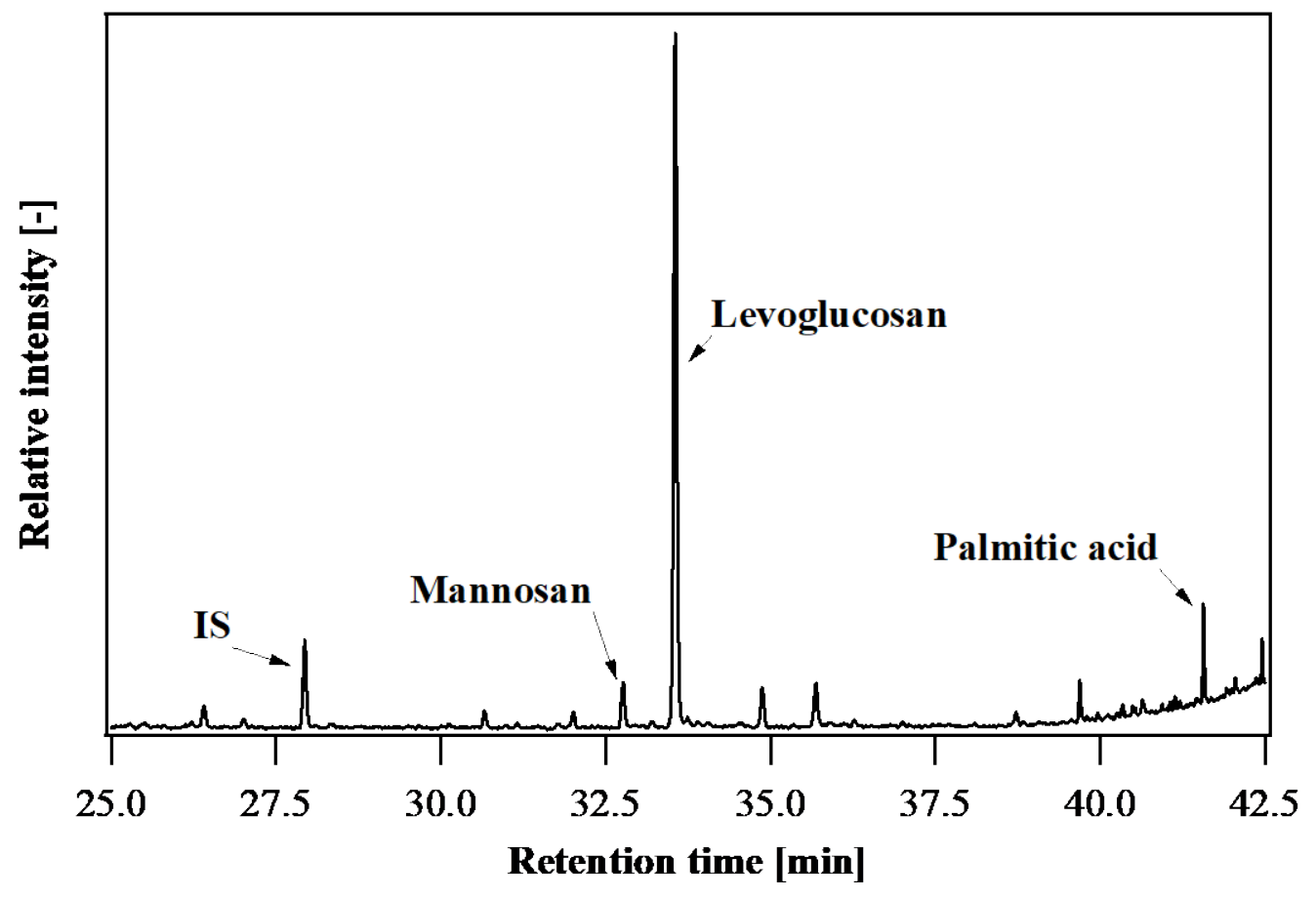

477 


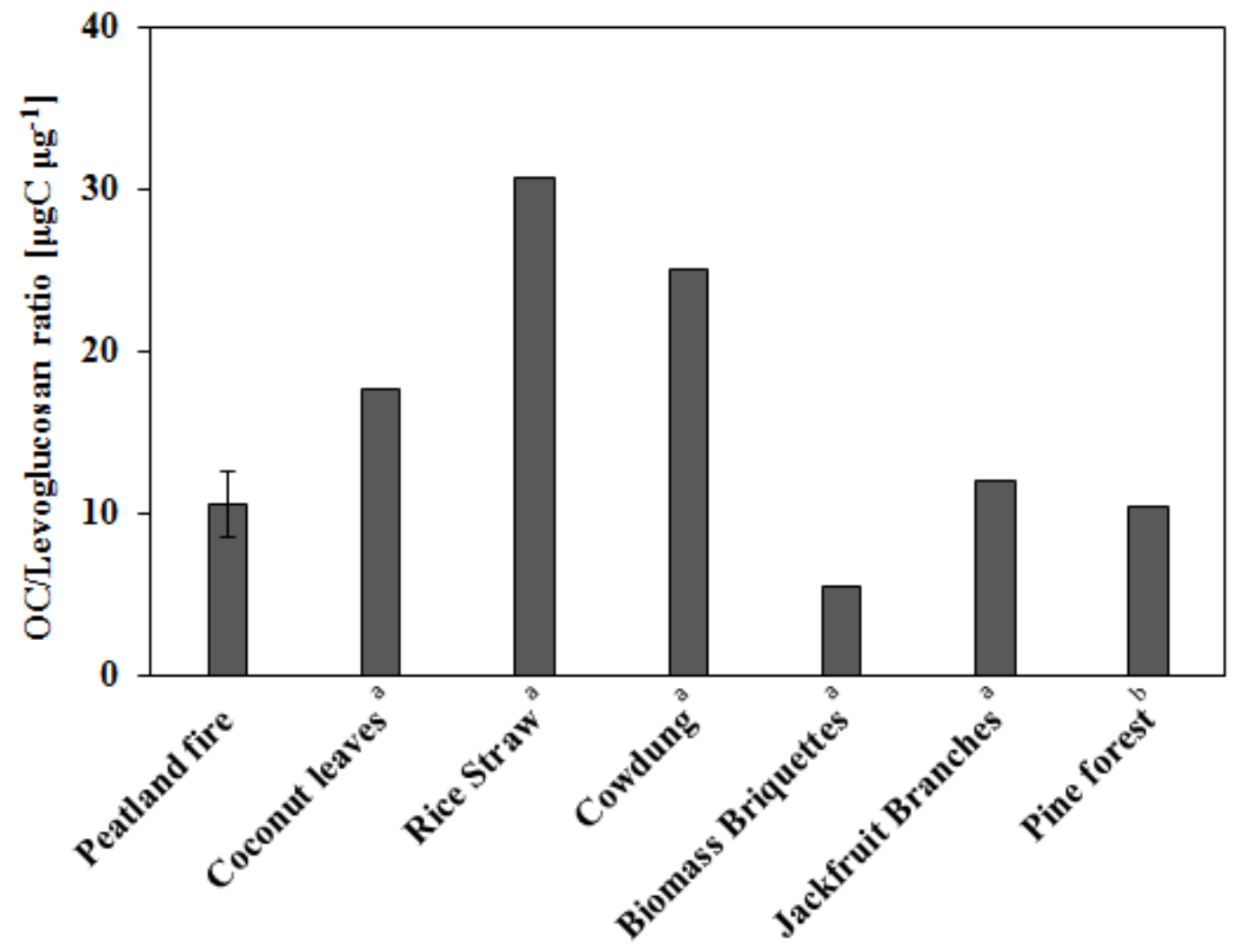

489 a data from Sheesley and Schauer, 2003, ${ }^{\text {b }}$ data from Lee et al., 2005. 